\title{
Can bark stripping cause red heartwood formation in beech stems?
}

\author{
Vladimír Račko(1), \\ Olga Mišíková (1), \\ Pavol Hlaváč (2), \\ Veronika Deáková ${ }^{(3)}$
}

\begin{abstract}
Injuries to standing trees caused by logging and the subsequent changes in biochemical composition and anatomy of affected tissues lead to wood quality loss, thus lowering the commercial value of roundwood. In this study, we investigated the influence of various factors that could help mitigate or prevent the spread of infections in the stem caused by injuries. A total of 112 beech logs (tree age: 42-143 years) from ten forest stands at three different sites in central Slovakia were examined, and the extent of discolouration and decay zones in each stem was measured, along with cambial age, stem diameter, injury width, and injury closure period. The results showed that the width of physiologically active wet sapwood and the width of the inactive dehydrated zone in the stem are important factors influencing red heartwood formation. We found no significant differences in the extent of discolouration and decay among different stands and sites. Stem diameter and injury width did significantly affect the penetration of infection through sapwood, and red heartwood formation was significantly affected by cambial age and injury width, while stand age, site slope, beech proportion in the stand and injury closure did not show any significant effect. Binary logistic models were applied to assess the probability of pathogen penetration through sapwood into the stem dehydrated zone as a function of injury width and stem diameter, as well as the probability that this could lead to red heartwood formation based on injury width and cambial age of beech stems.
\end{abstract}

Keywords: Sapwood Width, Dehydrated Zone Width, Discoloration Depth, Decay Depth, Red Heartwood Formation

ther invasion of pathogens and retard the decaying process of wood caused by fungi (Oven et al. 2010).

Sapwood is the outer zone of the stem which has an effective defence system to protect the vital functions of transport and reserves, restrict air embolism during the later stages, and limit the spread of pathogens (Dujesiefken et al. 2005). However, aging and maturation in some diffuse-porous species does not cause genetically-controlled metabolic changes leading to the transformation from sapwood to heartwood in the centre of the stem (Shigo \& Hillis 1973). The central non-coloured zone of the stem, known as "ripewood" (Necesany 1958) or "dehydrated zone" (especially in beech - Torelli 1984), is free of
(1) Department of Wood Science, Technical University in Zvolen, T.G.Masaryka 24, 96053 Zvolen (Slovakia); (2) Department of Integrated Forest Protection and Landscape, Technical University in Zvolen, T.G.Masaryka 24, 96053 Zvolen (Slovakia); (3) Institute of Foreign Languages, Technical University in Zvolen, T.G.Masaryka 24, 96053 Zvolen (Slovakia)

@ Vladimír Račko (racko@tuzvo.sk)

Received: Jun 21, 2016 - Accepted: Dec 27, 2017

Citation: Račko V, Mišíková O, Hlaváč P, Deáková V (2018). Can bark stripping cause red heartwood formation in beech stems? iForest 11: 251-258. - doi: 10.3832/ifor2147-011 [online 2018-03-12]

Communicated by: Giacomo Gol tyloses and polyphenolic compounds. These tissues show a reduced moisture content and a limited number of vital parenchyma cells (Jurášek 1956, Necesany 1958). Several developmental and environmental factors affect the formation and size of the dehydrated zone (Torelli 1984, Büren 1998, Fürst et al. 2006, Račko \& Cunderlík 2010); however, the age of the tree is a dominant factor in this process (Necesany 1958, Bosshard 1965).

Injury of a living stem enables pathogens to enter through the injured surface and penetrate deeper into the surrounding $\mathrm{xy}$ lem tissues. Faced with the risk of drying out and an expanding microbial infection, the sapwood efficiently defends its high moisture content, by forming tyloses in the vessels and triggering primary biochemical reactions. The capacity for defence is predominantly influenced by the physiological state of the tree (Dujesiefken et al. 1991, Shortle et al. 1996). If the pathogens entering through an injury overcome the strongest anatomical and biochemical barriers of the sapwood, a massive longitudinal spread of discolouration and decay can affect the dehydrated zone. The presence of discoloured wood in the middle of a stem, initiated by an injury, reduces the ratio of white coloured wood and thus lowers its commercial value (Baral et al. 2013). Apart from terms such as "discoloured wood" and "decay wood" (Shigo \& Hillis 1973), the terms "red heartwood", "wound heart- 
Tab. 1 - Main characteristics of the sampled stands at the three investigated sites. (Aa): Abies alba; (Ag): Alnus glutinosa; (Apl): Acer platanoides; (Aps): Acer pseudoplatanus; (Fe): Fraxinus excelsior; (Cb): Carpinus betulus; (Pa): Picea abies; (Ps): Pinus sylvestris; (Qp): Quercus petraea; (Qp): Quercus cerris; (Um): Ulmus montana; (*): concerning only beech.

\begin{tabular}{|c|c|c|c|c|c|c|c|c|c|c|c|}
\hline \multirow{2}{*}{ Characteristics } & \multirow{2}{*}{$\begin{array}{r}\text { Site } \\
\text { Stand }\end{array}$} & \multicolumn{5}{|l|}{ Mláčik } & \multicolumn{2}{|c|}{ Bukovina } & \multicolumn{3}{|l|}{ Trnie } \\
\hline & & 813 B & 737 & 352 & $806(4)$ & $744 \mathrm{~A}(1)$ & $626 \mathrm{~B}$ & 203(1) & $427 \mathrm{~A}$ & 545 & 339 \\
\hline Mean age (years) ${ }^{*}$ & & 70 & 110 & 115 & 135 & 160 & 110 & 130 & 65 & 90 & 110 \\
\hline Mean DBH $(\mathrm{cm})^{*}$ & & 26 & 42 & 56 & 42 & 42 & 48 & 47 & 25 & 34 & 55 \\
\hline Mean height $(m)^{*}$ & & 23 & 32 & 32 & 29 & 26 & 28 & 30 & 24 & 29 & 29 \\
\hline Beech proportion (\%) & & 80 & 51 & 49 & 50 & 9 & 75 & 15 & 85 & 55 & 51 \\
\hline Other species (\%) & & $\mathrm{Cb}-20$ & $\begin{array}{l}\text { Aa-22, } \\
\text { Fe-16, } \\
\text { Aps-6, } \\
\mathrm{Pa}-5\end{array}$ & $\begin{array}{l}\text { Qp-41, } \\
\text { Qc-10 }\end{array}$ & $\mathrm{Cb}-50$ & $\begin{array}{l}\text { Aps-43, } \\
\text { Fe-25, } \\
\text { Aa-13, } \\
\text { Apl-10 }\end{array}$ & $\begin{array}{l}\text { Cb-15, } \\
\text { Qp-5, } \\
\text { Qc-3, } \\
\text { Ps-2 }\end{array}$ & $\begin{array}{l}\text { Qp-50, } \\
\mathrm{Aa}-33, \\
\mathrm{~Pa}-2\end{array}$ & $\begin{array}{l}\text { Qp-5, } \\
\text { Cb -5, } \\
\text { Ag-5 }\end{array}$ & $\begin{array}{l}\text { Qp-25, } \\
\text { Pa-15, } \\
\text { Aa-5 }\end{array}$ & $\begin{array}{l}\text { Aps-29, } \\
\text { Apl-12, } \\
\text { Cb-8 }\end{array}$ \\
\hline Site quality* & & medium & good & good & poor & poor & medium & medium & good & good & medium \\
\hline Altitude (m a.s.l.) & & $300-450$ & $675-825$ & $430-460$ & $500-650$ & $680-800$ & $475-555$ & $590-690$ & $380-460$ & $445-590$ & $500-580$ \\
\hline Exposure & & SE & SE & E & E & SE & NE & SE & NE & E & $\mathrm{E}$ \\
\hline Slope (\%) & & 40 & 35 & 15 & 45 & 30 & 15 & 25 & 30 & 60 & 40 \\
\hline Thinning date & & 07-2012 & $03-2013$ & $01-2013$ & $02-2012$ & $04-2012$ & $07-2012$ & $09-2012$ & $02-2012$ & $05-2012$ & $09-2012$ \\
\hline Number of fell trees & & 23 & 28 & 25 & 23 & 27 & 22 & 26 & 24 & 26 & 24 \\
\hline Number of injuriies & & 16 & 8 & 7 & 9 & 11 & 10 & 12 & 17 & 11 & 11 \\
\hline
\end{tabular}

wood", "splash heartwood" and "abnormal heartwood" (Sachsse 1991) are frequently used to describe this phenomenon.

Discolouration and decay in the centre of beech stems (hereafter referred to as red heartwood) are predominantly caused by infection and oxygen penetrating through broken and dead branches (Kučera 1991, Büren 1998, Knoke \& Wenderoth 2001, Knoke 2003, Wernsdörfer et al. 2006, Schatz et al. 2008, Vartiamäki et al. 2009, Vasaitis et al. 2012). However, there is a lack of detailed information on whether bark stripping caused by logging can lead to red heartwood formation in beech.

The aim of this work was to evaluate: (i) if there is a link between the internal extent of discolouration and decay in the stem (in radial direction) and the external features on the injured surface; (ii) if there is a link between the extent of discolouration and decay in the stem (in radial direction) and different environmental conditions; (iii) what is the probability of discolouration and decay, caused by air penetration and microbial invasion (in radial direction) spreading through the sapwood into the central part of the stem; and (iv) what is the probability that the microbial infection entering the injury and penetrating into the dehydrated zone through sapwood is capable of causing extensive red heartwood formation.

\section{Material and methods}

Site characteristics and sample material Sample material was obtained from 10 different forest stands at three diffent locations belonging to the Forest Enterprise of the Technical University in Zvolen, Slovakia, situated in the orographic unit of Kremnické vrchy $\left(48^{\circ} 35^{\prime} 32.6^{\prime \prime} \mathrm{N}, 19^{\circ} 03^{\prime}\right.$ $45.0^{\prime \prime} \mathrm{E}-$ Tab. 1). The occurrence of fungi in the investigated forests was determined according to the phytopathological methodology of permanent monitoring plots (10 $\times 10 \mathrm{~m}$ ) in combination with random selection of transects with an area of $100 \times 10 \mathrm{~m}$ (Hlaváč \& Pavlík 2014 - Tab. S1 in Supplementary material). Trees were felled continuously during the vegetation and dormant period from February 2012 to March 2013. A total of 248 sample beech trees aged from 42 to 143 years with DBH ranging from 22.7 to $61.6 \mathrm{~cm}$, were obtained. This equates to approximately 25 trees per forest stand. Subsequently, the trees were cut into logs (3-5 m in length - Fig. 1a).

\section{Measurement of sapwood and}

dehydrated zone width at the time of felling

From each log, a $10 \mathrm{~cm}$ thick cross-section was cut (1063 cross sections in total - Fig. 1a). Within 30 minutes, a central dehydrated zone appeared on the freshly felled cross-sections, whilst the wetter outer zone was considered to be sapwood. Both zones, together with the stem diameter (measured from all the cross-sections along the tree height), were measured at the time of felling. Linear regression relationships between sapwood width and stem diameter, as well as between dehydrated zone width and stem diameter, were then determined (Fig. 2). Following these steps, the logs were used for estimating sapwood and dehydrated zone width at the time of injury closure.

Measurement of injury-related variables A total of 112 logs with visible wound scars were selected and sectioned through the middle of the injury (Fig. 1a). All injuries were caused by thinning operations, and were located randomly along the entire length of the tree stems. The length of injuries ranged from 0.12 to $0.86 \mathrm{~m}$. The centripetal discolouration depth and the decay depth on the log cross sections were determined as dependent variables, while the cambial age, stem diameter (both obtained at the time of injury closure), injury width and injury closure period were determined as independent variables (Fig. 1b). Cambial age and injury closure period were counted, whereas the remaining injury characteristics were measured. Cambial age denotes the total number of annual
Fig. 1 - (a) Scheme of stem cutting. (b) Graphical representation of the independent and dependent variables measured in this study (b).

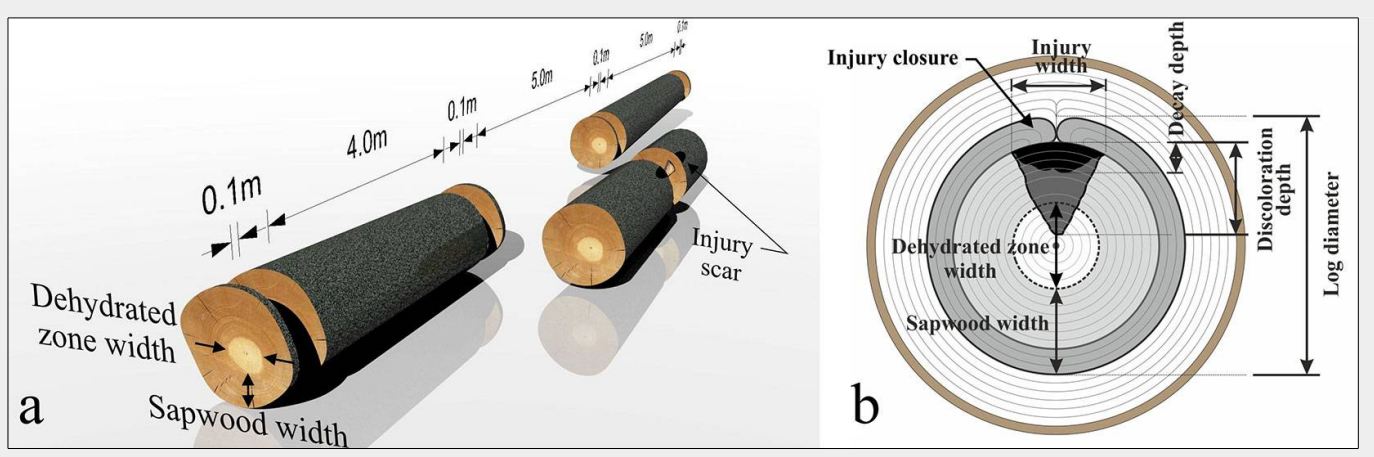


growth rings up to injury closure, whereas the injury closure period denotes the number of annual growth rings, starting with the origin of the injury and ending by closure of injury by lateral calluses.

Estimation of sapwood and dehydrated zone width at the time of injury closure

Stem diameters at the time of injury closure were measured on the faces of the cross-sectioned discs that contained discoloured and decayed zones only. Then, the probable sapwood width and dehydrated zone width at the time of injury closure were estimated (Fig. 1b), according to a linear regression relationship (Fig. 2).

\section{Estimation of sapwood penetration}

A discrete variable was designed to indicate if discolouration or decay have exceeded the sapwood boundary in each stem. The ratio $r_{1}$ between the discolouration depth and the sapwood width, and the ratio $r_{2}$ between the decay depth and the sapwood width, were calculated according to the following formulae (eqn. 1):

$$
r_{1}=\frac{D i D}{S W} \quad r_{2}=\frac{D e D}{S W}
$$

where DiD is the discolouration depth $(\mathrm{cm})$, $D e D$ is the decay depth $(\mathrm{cm}), S W$ is the sapwood width $(\mathrm{cm})$. If $r_{i}>1$, the sapwood boundary has been exceeded and the value "yes" was assigned to the discrete variable. If $r_{i}<1$, the sapwood boundary was not overcome and the discrete variable was given the value "not".

\section{Estimation of red heartwood} occurrence and size

The presence of red heartwood was as-

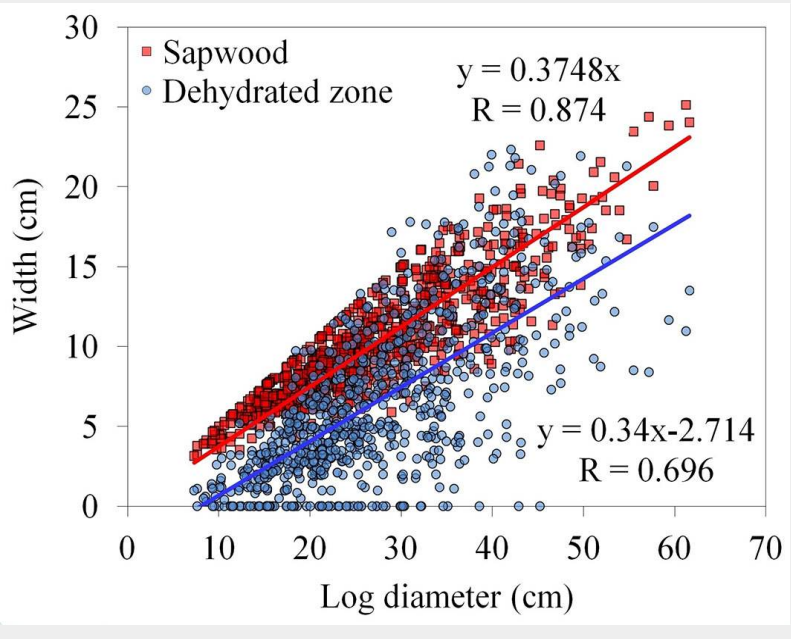

Fig. 2 - Relationship between stem diameter and sapwood width (red points) or dehydrated zone width (blue points).

sessed visually. Injuries with only wedgeshaped discoloured zones and unstained central dehydrated zones (Fig. 3a) were classified as injuries that did not cause the formation of red heartwood (discrete value "not"). On the other hand, injuries with wedge-shaped discoloured zones, centripetally expanding in width, and associated with central round discoloured zones (red heartwood - Fig. 3b) were classified as injuries that had a causal relationship with the formation of red heartwood (discrete value "yes"). Abnormally large, irregular-shaped heartwood exceeding the dehydrated zone was also included in the category of red heartwood (Fig. 3C).

The dimension of red heartwood was assessed by measuring its width in two perpendicular directions. The size of red heartwood was then calculated as the average value from the two measurements.

\section{Statistical analysis}

Descriptive statistics were calculated for each measured variable. Multiple linear regression analysis was applied using the following model (eqn. 2):

$$
y_{i}=b_{0}+b_{1} x_{1}+b_{2} x_{2}+b_{3} x_{3}+b_{4} x_{4}
$$

where $y_{i}$ represents the dependent variables ( $y_{1}$ : discolouration depth; $y_{2}$ : decay depth), $b_{0}$ is the intercept, $b_{1}-b_{4}$ are the regression coefficients, and $x_{1}-x_{4}$ are the predictors (independent variables, $x_{1}$ : cambial age, in years; $x_{2}$ : stem diameter, in $\mathrm{cm} ; x_{3}$ : injury width, in $\mathrm{cm} ; x_{4}$ : injury closure period, in years).

The correlation coefficients of the dependent variables with the predictor variables were calculated, and the significance of correlation and regression coefficients was tested for all regressions. Multiple analysis

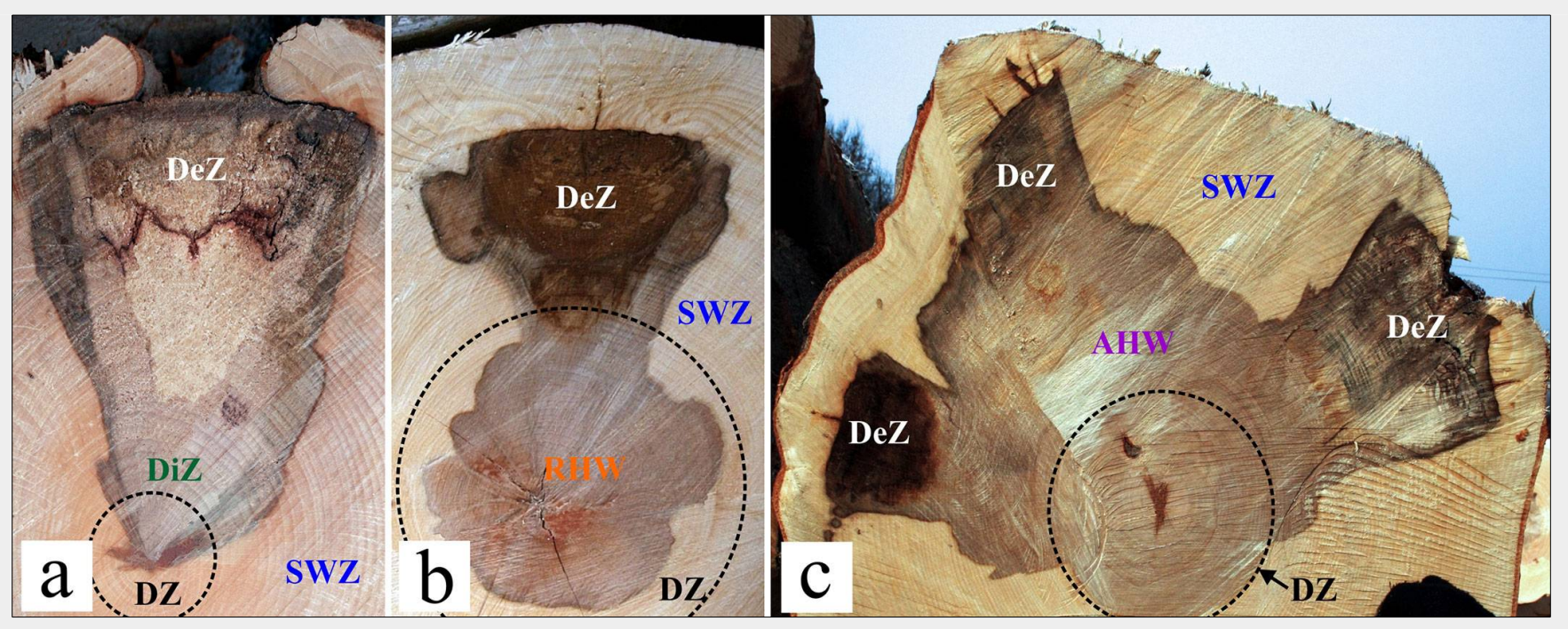

Fig. 3 - Classification of injuries: (a) Injuries not causing red heartwood formation; (b) Injuries causing red heartwood formation; (c) Injuries causing abnormal heartwood formation. (SWZ): sapwood zone (a wet marginal zone visible on freshly-felled cross sections of the tree trunks); (DZ): dehydrated zone (a paler and drier central part of the stem visible on freshly-felled cross sections of older tree trunks); (DiZ): discoloured zone (a wedge-shaped and pale brown-coloured zone in sapwood, sometimes exceeding dehydrated zone boundary); (DeZ): decayed zone (a wedge-shaped, dark brown or white-coloured zone localized in marginal parts of discoloured zones); (RHW): red heartwood (smaller central round-shaped and reddish brown-coloured zone formed in dehydrated zone); (AHW): abnormal heartwood (a large irregular-shaped and brown-coloured zone exceeding of dehydrated zone boundary and deeply extending into the sapwood zone). 
Tab. 2 - Descriptive statistics (mean \pm standard deviation) of all variables categorised according to the pathological status of injuries.

\begin{tabular}{lcccc}
\hline Variable & $\begin{array}{c}\text { Discoloration } \\
\text { zone only }\end{array}$ & $\begin{array}{c}\text { Discoloration } \\
\text { and decay zone }\end{array}$ & $\begin{array}{c}\text { Prob. } \\
(t \text {-test })\end{array}$ & $\begin{array}{c}\text { Total } \\
\text { cases }\end{array}$ \\
\hline$n$ & 48 & 64 & - & 112 \\
Cambial age & $53.9 \pm 19.5$ & $59.8 \pm 20.9$ & 0.632 & $50.3 \pm 19.3$ \\
Stem diameter & $26.8 \pm 12.6$ & $27.8 \pm 9.8$ & 0.064 & $23.2 \pm 10.0$ \\
Injury width & $4.4 \pm 2.6$ & $6.6 \pm 3.1$ & $<0.001$ & $5.6 \pm 3.1$ \\
Injury closure period & $5.6 \pm 2.6$ & $7.9 \pm 3.8$ & $<0.001$ & $6.9 \pm 3.5$ \\
Discoloration depth & $2.3 \pm 2.4$ & $6.7 \pm 5.7$ & $<0.001$ & $4.8 \pm 5.1$ \\
Decay depth & - & $3.7 \pm 3.6$ & - & $2.4 \pm 3.3$ \\
Sapwood width & $8.8 \pm 4.3$ & $8.6 \pm 3.3$ & 0.775 & $8.7 \pm 3.7$ \\
Dehydrated zone width & $5.3 \pm 3.9$ & $5.1 \pm 3.0$ & 0.753 & $5.2 \pm 3.4$ \\
\hline
\end{tabular}

of variance (ANOVA) and post-hoc Duncan's test were used to assess possible differences across different forest stands and sites. The software STATISTICA ${ }^{\circledast}$ ver. 10.0 (Stat Soft, Tulsa, OK, USA) was used for all analyses.

The probability of exceeding the sapwood boundary, and the probability of formation of discolouration and decay in the centre of the stem using the investigated factors as predictors were evaluated by binary logistic regression analysis. The binary logistic regression analysis was used to predict the probability of the discrete dependent variable $y$, which has a non-linear relationship with the linear predictor $x$. For the final transformation of the dependent variables into a linear one, a logarithm of odds (logit) was calculated. Then, the linear logistic models were described by the equation (eqn. 3):

$$
\begin{aligned}
& \operatorname{Logit}\left(p_{i, j}\right)=\ln \left(\frac{p}{1-p}\right)= \\
& =b_{0}+b_{1} x_{1}+b_{2} x_{2}+\ldots+b_{7} x_{7}
\end{aligned}
$$

where $p_{i, j}$ is the dependent variable $\left(p_{1, j}\right.$ is the probability that discolouration exceeds the sapwood boundary, $p_{2, j}$ is the probability that decay exceeds the sapwood boundary; $p_{3, j}$ is the probability of formation of discolouration and decay in the centre of the stem), $b_{0}$ is the intercept, $b_{1}-b_{7}$ are the regression coefficients, and $x_{1}-x_{7}$ are the independent variables $\left(x_{1}\right.$ : forest age, in years; $x_{2}$ : beech proportion, in \%; $x_{3}$ : slope, in \%; $x_{4}$ : cambial age, in years; $x_{5}$ : stem diameter, in $\mathrm{cm} ; x_{6}$ : injury width, in $\mathrm{cm} ; x_{7}$ : injury closure period, in years).

By means of reverse transformation, a non-linear relationship between the probability and the vector of independent variables was achieved (eqn. 4):

$$
p_{i, j}=\frac{e^{\left(b_{0}+b_{1} x_{1}+\ldots+b_{7} x_{7}\right)}}{1+e^{\left(b_{0}+b_{1} x_{1}+\ldots+b_{7} x_{7}\right)}}
$$

The open-source data-mining software Tanagra ver. 1.4.5 (http://eric.univ-lyon2.fr/ ricco/tanagra/) was used to calculate the odds ratio in the logistic anaysis and test for the statistical significance of the regression coefficients (Rakotomalala 2005). The global significance of the logistic models was tested by model fit statistics, model chi-squared test (likelihood ratio) and pseudo-R-like tests. Subsequently, the coefficients of the binary logistic regression models were tested by means of the Wald's chi-squared test, these being defined as the square root of ratios between the coefficients and their decisive errors (Hosmer \& Lemeshow 2005).

The logistic analyses were carried out in two steps. First, all the seven predictors were included in the initial analyses. Subsequently, the initial models were adjusted, discarding the non-significant variables pre- viously included. The adjusted models were then used to assess the relationship between transition probabilities and the significant independent variables, according to eqn. 4 .

\section{Results}

\section{Extent of discolouration and decay}

In 48 stems (of the 112 total) only wedgeshaped discoloured zones were present, whilst in the remaining 64 stems, decayed zones were also present (Tab. 2). The average depth of the decayed zones was lower than the average depth of the discoloured zones in all investigated samples; they reached approximately half the depth of the discoloured zones. Also between these variables, a relatively strong linear correlation relationship was found $(y=0.58 \cdot x ; r=$ 0.76 - Fig. S1 in Supplementary material). Moreover, stems containing decay zones showed significantly higher average values of injury width and injury closure period. On the contrary, there was no significant difference as far as cambial age and stem diameter were concerned (Tab. 2).

Despite all combinations of the investigated variables were considered, significant effects were observed only for linear regression models with a maximal of two independent variables ( $b_{1}$ and $b_{2}-$ Tab. 3 ). The high values of the correlation coefficients confirmed the relatively strong impact of injury width and injury closure period on the extent of discolouration and decay in radial direction. On the other hand, cambial age and stem diameter had a weak, or no impact. Although their individual effect was weak, some multiple regression models including both variables as predictors showed a relatively strong significance (Tab. 3).

The extent of discolouration and decay increased with the length of injury closure period. Discolouration depth accelerated with age, whereas decay depth at first also accelerated with age, but only up to 15 years, and afterwards decreased (Tab. S2 in Supplementary material).

\begin{tabular}{|c|c|c|c|c|c|c|}
\hline \multirow{2}{*}{$\begin{array}{l}\text { Dependent } \\
\text { variable }(y)\end{array}$} & \multicolumn{2}{|l|}{$\begin{array}{l}\text { Independent } \\
\text { variables }\end{array}$} & \multirow{2}{*}{$\begin{array}{l}\text { Intercept } \\
b_{0}\end{array}$} & \multicolumn{2}{|c|}{$\begin{array}{l}\text { Regression } \\
\text { coefficients }\end{array}$} & \multirow{2}{*}{$\begin{array}{l}\text { Correlation } \\
\text { coefficient }(r)\end{array}$} \\
\hline & $\left(x_{1}\right)$ & $\left(x_{2}\right)$ & & $b_{1}$ & $b_{2}$ & \\
\hline \multirow{6}{*}{$\begin{array}{l}\text { Discoloration } \\
\text { depth }(n=112)\end{array}$} & Cambial age & - & ns & $0.11^{* * *}$ & - & $0.401^{* * *}$ \\
\hline & Stem diameter & - & ns & $0.15^{* *}$ & - & $0.289^{* *}$ \\
\hline & Injury width & - & $-1.92^{* *}$ & $1.19^{* * *}$ & - & $0.728^{* * *}$ \\
\hline & Injury closure period & - & $-1.27^{* *}$ & $0.88^{* * *}$ & - & $0.610^{* * *}$ \\
\hline & Cambial age & Injury width & $-3.36^{* * *}$ & $0.04^{*}$ & $1.10^{* * *}$ & $0.741^{* * *}$ \\
\hline & Stem diameter & Injury closure period & $-3.09^{* *}$ & $0.09^{*}$ & $0.83^{* * *}$ & $0.636^{* * *}$ \\
\hline \multirow{4}{*}{$\begin{array}{l}\text { Decay depth } \\
(n=64)\end{array}$} & Cambial age & - & ns & $0.07^{* *}$ & - & $0.395^{* *}$ \\
\hline & Injury width & - & ns & $0.74^{* * *}$ & - & $0.642^{* * *}$ \\
\hline & Injury closure period & - & ns & $0.51^{* * *}$ & - & $0.536^{* * *}$ \\
\hline & Cambial age & Injury closure period & ns & $0.05^{*}$ & $0.44^{* * *}$ & $0.596^{* * *}$ \\
\hline
\end{tabular}

Tab. 3 - Significant linear regression and results of the correlation analysis between the investigated variables and the extent of dis coloration and decay. (ns): non significant; $\left({ }^{*}\right)$ : $p<0.05 ;(* *): p<0.01 ;(* * *): p<0.001$. 
Extent of discolouration and decay across different stands and sites

The extent of discolouration and decay differed only slightly among localities. Higher average values were found only in Bukovina. However, no significant difference in the extent of discolouration nor decay was observed in stems from different sites (Tab. 4). On the other hand, other values that could affect the extent of discolouration and decay were significantly different among the investigated sites.

Further analyses revealed a higher extent of discolouration and decay in stands with high average age, low proportion of beech versus other species, and low slope (stands 744 A1 and 203 (1) - Tab. 1, Tab. 5). High values of the extent of discolouration and decay were also found in other older stands, like 339 and 806 (4). Furthermore, injuries were more frequent in stems with higher cambial age in the stands $744 \mathrm{~A} 1$ and 203 (1). The average width of injuries was also higher, whilst the injury closure period in all investigated forests varied by only four years (Tab. 5).

\section{Probability of exceeding sapwood width}

The analysis of probabilities confirmed that only some of the investigated factors had a significant effect on the exceeding of discolouration and decay through the sapwood in the dehydrated zone. Globally-significant logistic models showed significant coefficients only for two predictors, namely stem diameter and injury width, whereas other independent factors, such as forest age, beech proportion, slope, cambial age, and injury closure period, did not show any

Tab. 4 - Mean \pm standard deviation of the variables considered in the three study sites and significance of their differences after ANOVA.

\begin{tabular}{lcccc}
\hline Variable & Mláčik & Bukovina & Trnie & Prob. \\
\hline$n$ & 51 & 22 & 39 & - \\
Cambial age & $59.3 \pm 21.9$ & $67.3 \pm 20.7$ & $48.9 \pm 14.8$ & 0.0017 \\
Stem diameter & $27.6 \pm 11.5$ & $32.9 \pm 12.7$ & $24.0 \pm 7.8$ & 0.0087 \\
Injury width & $5.7 \pm 2.7$ & $7.2 \pm 4.4$ & $4.8 \pm 2.4$ & 0.0142 \\
Injury closure period & $6.7 \pm 3.6$ & $8.5 \pm 4.0$ & $6.2 \pm 2.9$ & 0.0471 \\
Discolouration depth & $4.2 \pm 4.5$ & $6.9 \pm 7.4$ & $4.4 \pm 4.0$ & 0.0950 \\
Decay depth & $2.0 \pm 3.0$ & $2.7 \pm 4.3$ & $2.0 \pm 3.1$ & 0.6494 \\
\hline
\end{tabular}

significant effect (Tab. S3 and Tab. S4 in Supplementary material). Therefore, the final equation describing the transition probability of discolouration $\left(p_{1}\right)$ was defined as follows (eqn. 5):

$$
p_{1}=\frac{e^{\left(-1.9-0.13 x_{1}+0.79 x_{2}\right)}}{1+e^{\left(-1.9-0.13 x_{1}+0.79 x_{2}\right)}}
$$

while the final equation describing the transition probability of decay $\left(p_{2}\right)$ was as follows (eqn. 6):

$$
p_{2}=\frac{e^{\left(-3.18-0.11 x_{1}+0.56 x_{2}\right)}}{1+e^{\left(-3.18-0.11 x_{1}+0.56 x_{2}\right)}}
$$

where $x_{1}$ is the stem diameter and $x_{2}$ is the unjury width in both the above equations.

By increasing the stem diameter, the average value of the odds to exceed the sapwood decreases by only 1.14 times (1:0.88) in the case of discolouration, and 1.12 times (1:0.89) in the case of decay. On the other hand, the increase in width of the injury raises the average value of the odds by 2.21 times (2.21:1) in the case of discolouration, but only 1.74 times $(1.74: 1)$ in the case of decay (Tab. S3, Tab. S4 in Supplementary material). The variation of transition probabilities as a function of stem diameter injury width is displayed in Fig. 4.

\section{Probability of formation and extent of red heartwood}

Globally-significant logistic models of red heartwood formation confirmed the significance of two coefficients only, namely cambial age and injury width, while other investigated factors had no significant effect on red heartwood formation. The final equation describing the transition probability of red heartwood formation $\left(p_{3}\right)$ was defined as follows (eqn. 7):

$$
p_{3}=\frac{e^{\left(-7.99+0.06 x_{1}+0.39 x_{2}\right)}}{1+e^{\left(-7.99+0.06 x_{1}+0.39 x_{2}\right)}}
$$

where $x_{1}$ is the cambial age of the stem and $x_{2}$ is the unjury width.

With increased cambial age, the average odds of red heartwood formation in-

\begin{tabular}{|c|c|c|c|c|c|c|c|c|c|c|}
\hline \multirow{2}{*}{ Variable } & \multicolumn{5}{|l|}{ Mláčik } & \multicolumn{2}{|c|}{ Bukovina } & \multicolumn{3}{|l|}{ Trnie } \\
\hline & 813 B & 737 & 352 & $806(4)$ & 744 A1 & $626 \mathrm{~B}$ & $203(1)$ & $427 \mathrm{~A}$ & 545 & 339 \\
\hline$n$ & 16 & 8 & 7 & 9 & 11 & 10 & 12 & 17 & 11 & 11 \\
\hline Cambial age & $39.1 \pm 12.5$ & $58.0 \pm 17.7$ & $66.0 \pm 16.8$ & $62.3 \pm 14.2$ & $82.9 \pm 17.2$ & $59.4 \pm 18.3$ & $73.8 \pm 21.0$ & $42.3 \pm 11.7$ & $46.5 \pm 13.4$ & $61.6 \pm 13.3$ \\
\hline Stem diameter & $19.7 \pm 6.9$ & $25.0 \pm 6.9$ & $33.2 \pm 7.3$ & $28.3 \pm 9.9$ & $37.1 \pm 14.8$ & $30.8 \pm 13.2$ & $34.7 \pm 12.5$ & $22.6 \pm 7.3$ & $22.0 \pm 6.7$ & $28.0 \pm 8.8$ \\
\hline Injury width & $4.5 \pm 2.0$ & $5.2 \pm 2.2$ & $3.9 \pm 1.4$ & $7.1 \pm 3.4$ & $7.6 \pm 2.6$ & $5.8 \pm 4.4$ & $8.3 \pm 4.2$ & $4.5 \pm 1.9$ & $4.9 \pm 3.1$ & $5.0 \pm 2.4$ \\
\hline $\begin{array}{l}\text { Injury closure } \\
\text { period }\end{array}$ & $5.8 \pm 2.7$ & $8.1 \pm 5.4$ & $5.1 \pm 1.8$ & $7.8 \pm 4.3$ & $7.4 \pm 3.2$ & $7.2 \pm 3.5$ & $9.6 \pm 4.3$ & $6.1 \pm 2.3$ & $6.6 \pm 4.1$ & $6.1 \pm 2.4$ \\
\hline Discoloration depth & $2.3 \pm 2.1$ & $4.2 \pm 3.5$ & $3.5 \pm 5.1$ & $5.3 \pm 4.9$ & $6.7 \pm 6.1$ & $3.7 \pm 4.6$ & $9.6 \pm 8.3$ & $3.5 \pm 2.9$ & $3.8 \pm 3.1$ & $6.2 \pm 5.6$ \\
\hline Decay depth & $1.0 \pm 1.9$ & $1.7 \pm 2.6$ & $0.9 \pm 1.5$ & $2.3 \pm 2.2$ & $4.2 \pm 4.6$ & $0.6 \pm 1.2$ & $4.5 \pm 5.1$ & $1.0 \pm 1.9$ & $2.1 \pm 2.8$ & $3.3 \pm 4.5$ \\
\hline
\end{tabular}
creased by 1.06 times only (1.06:1); how-

Tab. 5 - Descriptive statistics for the studied variables in different forest sites and stands.

Fig. 4 - Transition probabilities of exceeding the sapwood boundary for (a) discoloration and (b) decay in beech stems as a function of injury width ( $x$-axis) at different stem diameters (different coloured lines).

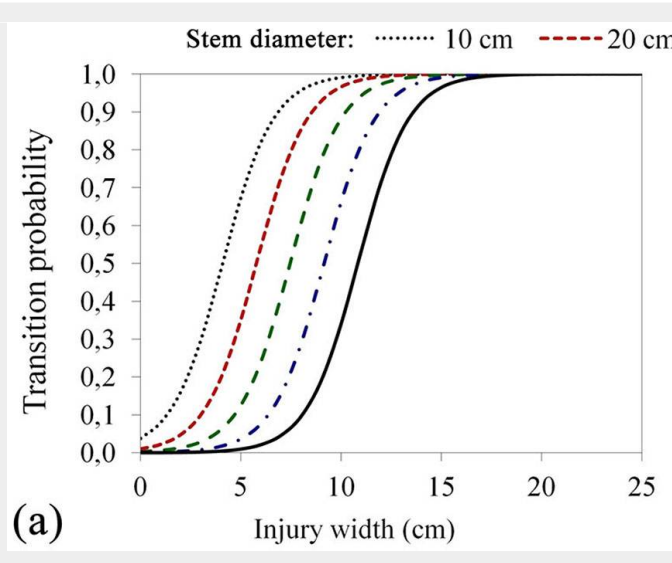

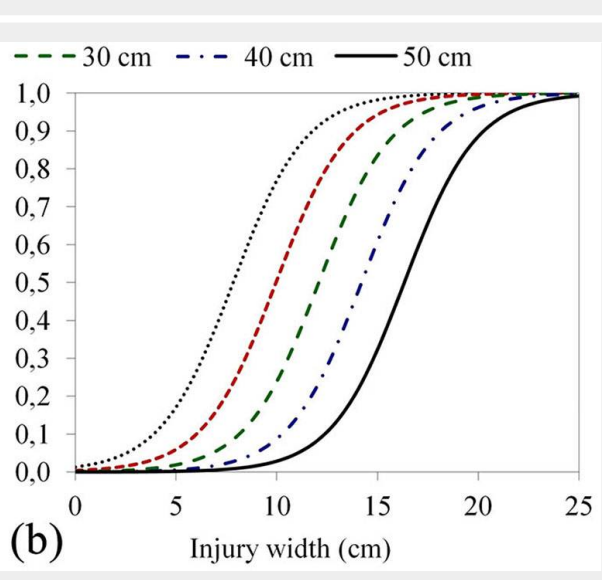


Fig. 5 - Transition probability of red heartwood

formation in beech stem as a function of injury width ( $x$-axis) at different cambial ages (different coloured lines).

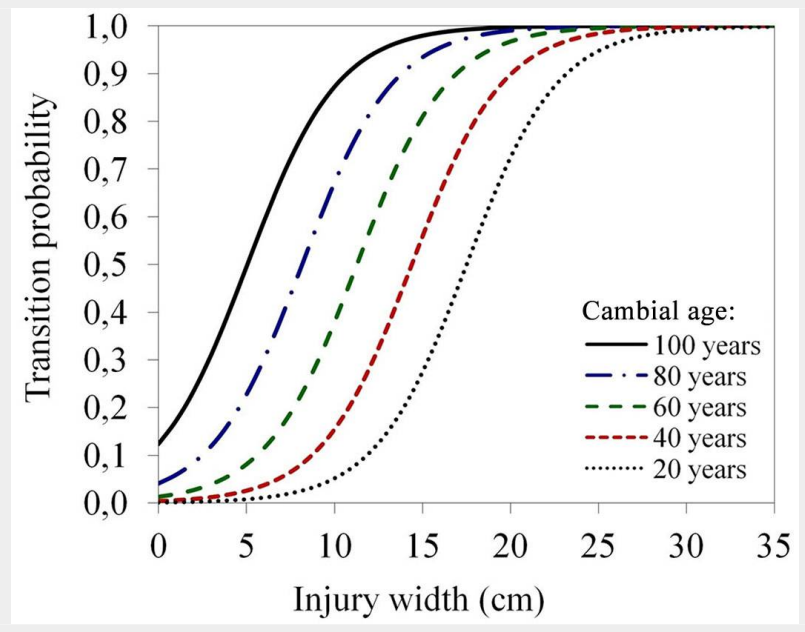

ever, the increase in width of the injury raised the average odds by 1.47 times (1.47:1 - Tab. S5 in Supplementary material). The transition probability of red wood formation as a function of cambial age and injury width is displayed in Fig. 5 .

The results confirmed the assumption that a relatively strong correlation $(r=$ $0.635, p=0.002$ ) exists between the size of the dehydrated zone and red heartwood. In most cases, the average value of red heartwood width was less than that of the estimated dehydrated zone. Only in three out of 20 cases the width of red heartwood was higher (Fig. S2 in Supplementary material). Also, cambial age had a relatively strong effect on red heartwood width $(r=$ $0.645, p=0.003-$ Fig. S3 in Supplementary material). Therefore, the higher the cam bial age of the stem, the greater the red heartwood width; however, injury width had a very weak effect $(r=0.163, p=0.026$ - Fig. S4).

\section{Discussion}

All investigated injuries contained at least a minimal extent of discolouration, contrasting to the findings of Schumann \& Dimitri (1993), Hecht et al. (2015) and Schulz (1973), who reported that only $64 \%$, $70 \%$ and $82 \%$ of 3 -year-old open wounds contained discolouration in beech, respectively. Injuries with a lower average width and a shorter time period of injury closure did not contain decayed zones (Tab. 2). Decayed zones were present only in larger injuries with a longer time period of injury closure. According to Shortle et al. (1996), decay in living trees occurs only in wood that has previously been discoloured. Also, it is generally known that larger and older wounds are more likely to be colonised by fungi (Vasiliauskas \& Stenlid 1998b, Vasiliauskas 2001). In our case, $57 \%$ of injuries contained decay zones; however, Schumann \& Dimitri (1993) found only $25 \%$ of wounds due to logging which were infected by fungi. The extent of decay in radial direction was present in $49 \%$ of our cases, where they expanded by only $1 \mathrm{~cm}$ over three years. This means that beech is more resistant to wound-invading microorganisms, as compared with other species (Diehl \& Seidenschnur 1990). However, discolouration at later stages of wood decay poorly inhibits the spread of decay. On the other hand, the reaction zone represents a strong and persistent static barrier against decay lesions (Pearce 1991). Therefore, the lower depth of decay compared to discolouration is probably due to a delay in the spread of wood decay (Fig. S1 in Supplementary material).

The injury width has a dominant impact on the extent of discolouration and decay of beech stems (Tab. 3), similarly to birch (Vasaitis et al. 2012), whereas the impact is weak in ash (Vasiliauskas \& Stenlid 1998a). The injury closure period is also positively and linearly correlated with the extent of both discolouration and decay in beech (Tab. 3). The prolonged invasion of pathogens via open injuries enables the infection to penetrate deeper into the wooden tissues of the stem, whereas a weaker compartmentalisation allows an increase in the spreading rate of the discolouration and decay. Contrary to Vasaitis et al. (2012), we found no significant difference in stem discolouration between open and occluded injuries in beech. Also, there was no significant correlation, as found in birch (Vasaitis et al. 2012) or in ash (Vasiliauskas \& Stenlid 1998a). in this study, cambial age and stem diameter had the weakest correlation (Tab. 3), similar to the findings of Vasiliauskas \& Stenlid (1998a) in ash.

Our results indicated that the extent of discolouration and decay depth in injuries was similar across different localities and stands. Small differences in some forest stands were influenced by a different cambial age, trunk diameter, injury width and injury closure period. Such differences could also be affected by the physiological state of individual trees (Dujesiefken et al. 1991, Shortle et al. 1996), the season of injury (Dujesiefken \& Liese 1990, Dujesiefken et al. 2005), climatic conditions in the year of injury, different micro-organisms, pathogens, or saprophytes etc. Indeed, we observed a higher extent of discolouration and decay only in stands $744 \mathrm{~A} 1$ and 203 (1) from Bukovina (Tab. 4 and Tab. 5).

Biochemical processes and the moisture content of intact sapwood in beech represent a relatively strong defence barrier against the invasion of pathogens. On the other hand, the centripetal decreasing humidity and the sap flow density in beech stems (Gessler et al. 2005) may facilitate the penetration of air and pathogens into the inner parts. Overall, the difference in the extent of discolouration and decay at different heights along the stem was only 0.1-0.4 $\mathrm{m}$ in depth $(\max 10 \mathrm{~cm})$ over a three year-exposure (Dujesiefken \& Liese 1990), whereas it does not exceed 1.5-2 m during longer-term exposure (Dujesiefken et al. 1991, 1999).

We found that not all injuries that exceeded the sapwood caused the formation of red heartwood. In the $32 \%$ of discoloured cases and $9 \%$ of decayed cases that exceed the sapwood, less than half of them (19\%) led to red heartwood formation. In terms of typology, according to Sachsse (1991), only $2.7 \%$ of red heartwood cases are categorised as abnormal heartwood (Fig. 3c). Further, all the monitored factors had no significant effect on the probability of exceeding the sapwood (Tab. S3 and Tab. S4 in Supplementary material) and forming red heartwood (Tab. S5).

Injured stems having a large diameter showed a lower probability that infection will exceed the sapwood, as pathogens have to travel a longer distance. Conversely, wider injuries have odds that are significantly higher (Fig. 4a and Fig. 4b). Cambial age and injury width also have a significant impact on the probability of red heartwood formation (Fig. 5, Tab. S5 in Supplementary material). Previous studies reported that tree age and diameter at breat height have a dominant effect on the frequency and size of red heartwood (Kladtke 2002, Knoke 2002, 2003, Wernsdörfer et al. 2006). Krempl \& Mark (1962) also assumed that large wounds could be the initiation point of red heartwood formation. Sachsse $\& \mathrm{Si}$ monsen (1981) stated that the transformation from "wound heartwood" (discolouration of sapwood) to red heartwood may gradually occur in trees older than 75-90 years. Age-related alteration of vital parenchyma rays and moisture content in the dehydrated zone lead to an increased susceptibility to red heartwood formation in older trees. This is also supported by our findings that cambial age and dehydrated zone width are correlated with red heartwood width (Fig. S2 and Fig. S3 in Supplementary material), though the effect of injury width on red heartwood width was weak (Fig. S4). According to Fürst et al. (2006), further studies should focus on the starting age/diameter of "dry heartwood" formation (analogous to dehydrated zone, or ripewood) in European beech to elucidate the above relationship. Indeed, the "dry heartwood" has the potential for later red 
heartwood formation, and thus can be used as an indicator for the risk of later wood quality loss.

\section{Conclusions}

We conclude that only large stem injuries caused by bark stripping during thinning operations have the potential to initiate red heartwood formation in European beech. In particular, the width of sapwood and the dehydrated zone may affect such process. In this study, no significant difference in discoloration, decay and red heartwood formation were found across different sites and beech stands.

Although thinning can promote the growth of standing trees, intense interventions may cause frequent and large injuries on the stems, thus increasing the risk of infection that could cause an intensive red heartwood formation in aged beech trees. Therefore, the adoption of appropriate thinning strategies could reduce massive stem injuries and the probability of red heartwood formation in older target trees.

\section{Acknowledgements}

We acknowledge the support from the Scientific Grant Agency of the Ministry of Education SR and the Slovak Academy of Sciences Grant No. 1/0822/17. This work was also supported by funding from the Slovak Research and Development Agency under the contracts no. APVV-16-0177 and no. APVV-0744-12.

\section{References}

Albert L, Hofmann T, Németh Z, Rétfalvi T, Koloszár J, Varga, S, Csepregi, I (2003) Radial variation of total phenol content in beech (Fagus sylvatica L.) wood with and without red heartwood. European Journal of Wood and Wood Products 61: 227-230. - doi: 10.1007/s00107-0030381- $\mathrm{x}$

Baral SK, Schneider R, Pothier D, Berninger $F$ (2013). Predicting sugar maple (Acer saccharum Marsh.) discoloured wood characteristics. Canadian Journal of Forest Research 43: 649-657. - doi: 10.1139/cjfr-2013-0017

Bosshard HH (1965). Aspects of the aging process in cambium and xylem. Holzforschung 19 (3): 65-69. - doi: 10.1515/hfsg.1965.19.3.65

Büren S (1998). Buchenrotkern: Erkennung, verbreitung und wirtschaftliche bedeutung. [Red heartwood formation in beech: identification, occurrence and economic importance]. Schweizerische Zeitschrift fur Forstwesen 149 955970. [in German]

Diehl M, Seidenschnur W (1990). Gutes Überwallungsvermögen der Rotbuche bei Schälschäden im Dickungsstadium [Good occlusion capability in beech after bark-stripping damage in the thicket stage]. Allgemeine Forstzeitschrift: 452454. [in German]

Dujesiefken D, Liese W (1990). Einfluß der Verletzungszeit auf die Wundheilung bei Buche ( $\mathrm{Fa}$ gus sylvatica L.) [Time of wounding and wound healing in beech (Fagus sylvatica L.)]. European Journal of Wood and Wood Products 48: 95-99. [in German] - doi: 10.1007/BF02619653

Dujesiefken D, Liese W, Shortle W, Minocha R
(2005). Response of beech and oaks to wounds made at different times of the year. European Journal of Forest Research 124: 113-117. - doi: 10.1007/s10342-005-0062-x

Dujesiefken D, Peylo A, Liese W (1991). Einfluß der Verletzungszeit auf die Wundreaktionen verschiedener Laubbäume und der Fichte [Influence of time of wounding on the wound reactions of various broadleaves and Norway spruce]. Forstwissenschaftliches Centralblatt 110:371-380. [in German] - doi: 10.1007/BF0274 1270

Dujesiefken D, Rhaesa A, Eckstein D, Stobbe $\mathrm{H}$ (1999). Tree wound reactions of differently treated boreholes. Journal of Arboriculture 25: 119-123. [online] URL: http://www.researchgat e.net/publication/265273019

Fürst C, Seifert T, Makeschin F (2006). Do site factors affect the wood quality of European beech (Fagus sylvatica L.)? Results from a prestudy on red heartwood. Forst und Holz 61: 464-468.

Gessler A, Rienks M, Dopatka T, Rennenberg H (2005). Radial variation of sap flow densities in the sapwood of beech trees (Fagus sylvatica). Phyton 45: 257-266. [online] URL: http://www. researchgate.net/publication/215919655

Hecht U, Kohnle U, Nill M, Grüner J, Metzler B (2015). Bark wounds caused by felling are more susceptible to discoloration and decay than wounds caused by extraction in European beech. Annals of Forest Science 72: 731-740. doi: 10.1007/s13595-014-0432-y

Hlaváč P, Pavlík M (2014). Atlas lesnícky významných húb rastúcich v porastoch VšLP TU vo Zvolene [Atlas of forestry important fungi growing in forests of Forest Enterprise the Technical University Zvolen]. Technical university press, Zvolen, Slovakia, pp. 159. [in Slovak]

Hosmer DW, Lemeshow S (2005). Applied logistic regression. John Wiley and Sons, Inc., New York City, USA, pp. 383.

Jurášek L (1956). Vznik thyl v bukovém dreve. [Tylosis formation in beech wood]. Wood Research 1: 7-15. [in Slovak]

Kladtke J (2002). Wachstum großkroniger Buchen und waldbauliche Konsequenzen. [Growth of beeches with large crowns and consequences for silviculture]. Forstarchiv 73: 211-217. [in German]

Knoke T (2002). Value of complete information on red heartwood formation in beech (Fagus sylvatica). Silva Fennica 36: 841-851. - doi: 10.142 $14 /$ sf. 525

Knoke T (2003). Predicting red heartwood formation in beech trees (Fagus sylvatica L.). Ecological Modelling 169: 295-312. - doi: 10.1016/S03 04-3800(03)00276-X

Knoke T, Wenderoth SS (2001). Ein Ansatz zur Beschreibung von Wahrscheinlichkeit und Ausmass der Farbkernbidung bei Buche (Fagus sylvatica L.). [An approach to predict probability and extent of red coloured heartwood in beech (Fagus sylvatica L.)]. Forstwissenschaftliches Centralblatt 120: 154-172. [in German] - doi: 10.1007/BF02796089

Krempl H, Mark E (1962). Untersuchungen über den kern der rotbuche [Studies of red heartwood in beech]. Allgemeine Forst Zeitung 73: 186-191. [in German]

Kučera LJ (1991). Die buche und ihr holz - eine einfuhrung in die problematik [The beech and its wood - an introduction to the problem]. Schweizerische Zeitschrift für Forstwesen 142: 363-373. [in German]

Necesany V (1958). Jadro buku: struktura, vznik a vyvoj [Beech heartwood: structure and formation]- Slovak Academy of Sciences, Bratislava, Slovakia, pp. 231. [in Slovak]

Oven P, Merela M, Vek V (2010). Response of wood in beech to mechanical wounding. In: Proceedings of the " 6 th IUFRO Symposium Wood Structure and Properties 10" (Lagana JKR ed). Podbanske, High Tatras, Slovakia Arbora Publishers, pp. 63-66 [online] URL: http://books.google.com/books?id=r4r7A7W4S BQC

Pearce RB (1991) Reaction zone relics and the dynamics of fungal spread in the xylem of woody angiosperms. Physiological and Molecular Plant Pathology 39: 41-55. - doi: 10.1016/0885-5765 (91)90030-L

Račko V, Cunderlík I (2010). Zrelé drevo ako limitujúci faktor vzniku nepravého jadra buka ( $F a-$ gus sylvatica L.) [The ripewood as a limiting factor of the false heartwood formation of beech (Fagus sylvatica L.)]. Acta Facultatis Xylologiae 52: 15-24. [in Slovak]

Rakotomalala R (2005). TANAGRA: a free software for research and academic purposes. In: Proceedings of the Meeting "EGC 2005" (RNTIE-3 ed). Amsterdam, Netherlands, pp. 697-702. Sachsse H (1991). Kerntypen der rotbuche [Type of beech heartwoods]. Forstarchiv 62: 238-241. [in German]

Sachsse H, Simonsen D (1981). Untersuchung über mögliche Zusammenhänge zwischen mechanischen Stammverletzungen und Kernbildung bei Fagus sylvatica [Investigation on eventual relations between artificial stem wounds and heartwood formation in Fagus sylvatica]. Forstarchiv 52: 179-183. [in German]

Schatz $\mathrm{U}$, Heräjärvi $\mathrm{H}$, Kannisto $\mathrm{K}$, Rantatalo $\mathrm{M}$ (2008). Influence of saw and secateur pruning on stem discolouration, wound cicatrisation and diameter growth of Betula pendula. Silva Fennica 42: 295-305. - doi: 10.14214/sf.258

Schulz H (1973). Auswirkungen von Rückeschäden an jungen Buchen und Edellaubhölzern [Effect of logging wounds in young beech and other hardwoods]. Holzforschung 27: 43-47. [in German] - doi: 10.1515/hfsg.1973.27.2.42

Schumann G, Dimitri L (1993). Wunden und wundfäulen bei der Buche. [Wounds and wound rot in beech]. Allgemeine Forstzeitschrift 48: 456-460. [in German]

Shigo AL, Hillis WE (1973). Heartwood, discolored wood, and microorganisms in living trees. Annual Review of Phytopathology 11: 197-222. doi: 10.1146/annurev.py.11.090173.001213

Shortle WC, Smith KT, Dudzik KR (1996). Decay diseases of stemwood: detection, diagnosis, and management. In: "Forest trees and palms" (Raychaudhuri SP, Maramorosch K eds). Oxford and IBH Publishing, New Delhi, India, pp. 95-109. [online] URL: http://www.fs.usda.gov/ treesearch/pubs/15514

Torelli N (1984). The ecology of discolored wood as illustrated by beech (Fagus sylvatica L.). IAWA Bulletin 5: 121-127. - doi: 10.1163/2294193290000875

Vartiamäki H, Hantula J, Uotila A (2009). Suscep- 
tibility of silver birch pruning wounds to infection by white-rot fungus (Chondrostereum purpureum), a potential bioherbicide. Silva Fennica 43: 537-547. - doi: 10.14214/sf.179

Vasaitis R, Bakys R, Vasiliauskas A (2012). Discoloration and associated fungi in stems of silver birch (Betula pendula Roth.) following logging damage. Forest Pathology 42: 387-392. - doi: 10.1111/j.1439-0329.2012.00771.x

Vasiliauskas R (2001). Damage to trees due to forestry operations and its pathological significance in temperate forests: a literature review. Forestry 74: 319-336. - doi: 10.1093/forestry/74. 4.319

Vasiliauskas R, Stenlid J (1998a). Discoloration following bark stripping wounds on Fraxinus excelsior. European Journal of Forest Pathology 28: 383-390. - doi: 10.1111/j.1439-0329.1998.tbo11 92.x

Vasiliauskas R, Stenlid J (1998b). Fungi inhabiting stems of Picea abies in a managed stand in Lithuania. Forest Ecology and Management 109:
119-126. - doi: 10.1016/S0378-1127(98)00226-6 Wernsdörfer H, Le Moguedec G, Constant T, Mothe F, Nepveu G, Seeling U (2006). Modelling of the shape of red heartwood in beech trees (Fagus sylvatica L.) based on external tree characteristics. Annals of Forest Science 63: 905913. - doi: 10.1051/forest:2006074

\section{Supplementary Material}

Tab. S1 - List of pathogens found at the three study sites.

Tab. S2 - Extent of discoloration and decay of injuries with different range of injury closure period.

Tab. S3 - Attributes of the binary logistic model describing the probability of penetration of discoloration through the sapwood into the central part of the stem.
Tab. S4 - Attributes of the binary logistic model describing the probability of penetration of decay through the sapwood into the central part of the stem.

Tab. S5 - Attributes of the binary logistic model describing the probability of red heartwood formation.

Fig. S1 - Relationship between discoloration and the decay depth.

Fig. S2 - Relationship between dehydrated zone width and red heartwood width.

Fig. S3 - Relationship between cambial age and red heartwood width.

Fig. S4 - Relationship between injury width and red heartwood width.

Link: Racko_2147@supplo01.pdf 